\title{
Trafik Sıkışıklığının Azaltılmasında Ulaşım Çözümlerinin Etkisi
}

\author{
Mustafa Ilıcalı ${ }^{1}$ (D), Süleyman Saraç ${ }^{2 *}$ \\ ${ }^{1}$ İstanbul Ticaret Üniversitesi, İstanbul, Türkiye \\ ${ }^{2}$ Kocaeli Büyükşehir Belediyesi, Kocaeli, Türkiye
}

$\ddot{O} \mathbf{z}$

Günümüzde her geçen gün maddi imkânların ve teknolojik gelişmelerin artması sonucu kentlerde trafik sıkışıklıkları ve yoğunlukları artmaya başlamış, bununla beraber hava kirliliği ve zaman kayıpları da artmaya başlamıştır. İnsanların trafikte geçirdikleri zamanın artmasıyla kent yöneticileri ve ulaşım planlamacılar yeni yollar ve yeni ulaşım yatırımları yaparak bu sorunun önüne geçmeyi hedeflemişlerdir. Fakat yapılan yeni ulaşım yatırımları ve yollarda trafik sıkışılığının önüne geçememiştir. Bu çalışmada Kocaeli ili sınırlarında trafik sıkışıklığının gözlemlendiği Gölcük Koridoru irdelenerek ulaşım yatıımlarının trafik sıkışıklığına etkileri PTV Group Vissim yazılımı yardımıyla analiz edilecektir. Yazılım yardımıyla koridor boyunca mikro simülasyon modeli oluşturularak halihazırda işleyen mevcut trafik akışı daha önceden yapılan trafik sayımları verileri kullanılarak analiz edilmiştir. Öneri olarak geliştirilen senaryolarda aynı trafik hacminde test edilerek, koridor üzerinde yapılması planlanan projelerin çözüme katkısı karşılaştırılacaktır.

Anahtar Kelimeler: ulaşım, trafik güvenliği, trafik sıkışıklığı, planlama

\section{The Effect of Transportation Solutions in Reduction of Traffic Compression}

\begin{abstract}
Nowadays, as a result of the increase in financial opportunities and technological developments, traffic congestions and densities started to increase in cities and air pollution and time losses started to increase. With the increase in the time people spend in traffic, city managers and transportation planners have aimed to prevent this problem by making new roads and new transportation investments. However, new transportation investments and roads could not prevent traffic congestion. In this study, the effects of transportation investments on traffic congestion will be analyzed with the help of PTV Group Vissim software. The software developed a micro building model in the port corridor and analyzed the current traffic situation in the planning of traffic counts. The proposal compares the contribution of the scripts to the solution of the projects planned to be planned on the corridor, test rooms with the same traffic volume.
\end{abstract}

Keywords: transportation, traffic safety, traffic congestion, planning

\footnotetext{
* Iletişim / Contact: Süleyman Saraç, Kocaeli Büyükşehir Belediyesi, Kocaeli Türkiye. E-Posta / E-mail: suleymansarac@kocaeli.bel.tr.

Gönderildiği tarihi / Date submitted: 17.05.2019, Kabul edildiği tarih / Date accepted: 29.09.2019

Alıntı / Citation: Ilıcalı, M. ve Saraç S. (2019). Trafik sıkışıklığının azaltılmasında ulaşım çözümlerinin etkisi. Trafik ve Ulaşım Araştırmaları Dergisi, 2(2), 93-107.
} 


\section{Trafik Sıkışıklığının Azaltılmasında Ulaşım Çözümlerinin Etkisi}

Kocaeli İstanbul ve Ankara kentleri arasında konumlanmış karayolu, denizyolu ve demiryolu gibi farklı ulaşım modlarında güçlü bağlantılara sahip, gelişmiş sanayisi ise yalnızca kentsel ya da bölgesel değil, ulusal ölçekte katma değer sağlayan metropol karakterli bir kenttir.

Kocaeli Büyükş̧ehir Belediyesi'nin sınırları Kocaeli il sınırlarını kapsamaktadır. 3.418 km'lik büyükşehir sınırları içinde 12 ilçe bulunmaktadır. Türkiye İstatistik Kurumu [TÜİK], Adrese Dayalı Nüfus Kayıt Sistemi verilerine göre Kocaeli İl nüfusu 1.906.391 kişi, Kocaeli kenti güney kesiminde yer alan Gölcük ilçesinin nüfusu ise 162.584 kişidir (TÜİK, 2018).

Yürütülmekte olan mevcut çalışmanın amacı; Gölcük kentinin mevcut durumdaki sorunlarının tespit edilmesi ve saha gözlemleri ile trafik sayımları doğrultusunda belirlenen sorunlarla ilgili gerekli analizleri gerçekleştirerek çözümler üretilmesidir. Bu kapsamda kent merkezinde tüm ulaşım türleri arasında bütünleşik bir sistem oluşturulması, yaya ve bisikletliler için güvenliği ön planda tutarak konforlu alanlar yaratılması için iki farklı çözüm önerisi getirilmiş ve karşılaştırma analizleri yapılmıştır.

\section{2. Çalışma Alanı ve Yaşanan Sorunların İrdelenmesi}

Çalışılacak D-130 Karayolu kent geçişi kesimi, batısında Karaağaç Caddesi yakınlarında bulunan üst geçitten başlayarak doğuda yaklaşık $3.8 \mathrm{~km}$ devam ederek İhsn. Kazım Karabekir Caddesi hizasında son bulmaktadır. (Bkz: Şekil 1) D-130 Karayolu Kocaeli kentinde birçok ilçede olduğu gibi çevreyolu mantığının aksine yerleşim bölgesinin arasından geçmekte ve kenti ikiye bölmektedir. Bu durum, hem transit trafiğin akışının olumsuz etkilenmesi ve kent trafiğinin de aksamasına neden olmakta hem de kentin özellikle kuzey - güney doğrultulu yaya geçişlerini olumsuz etkilemektedir.

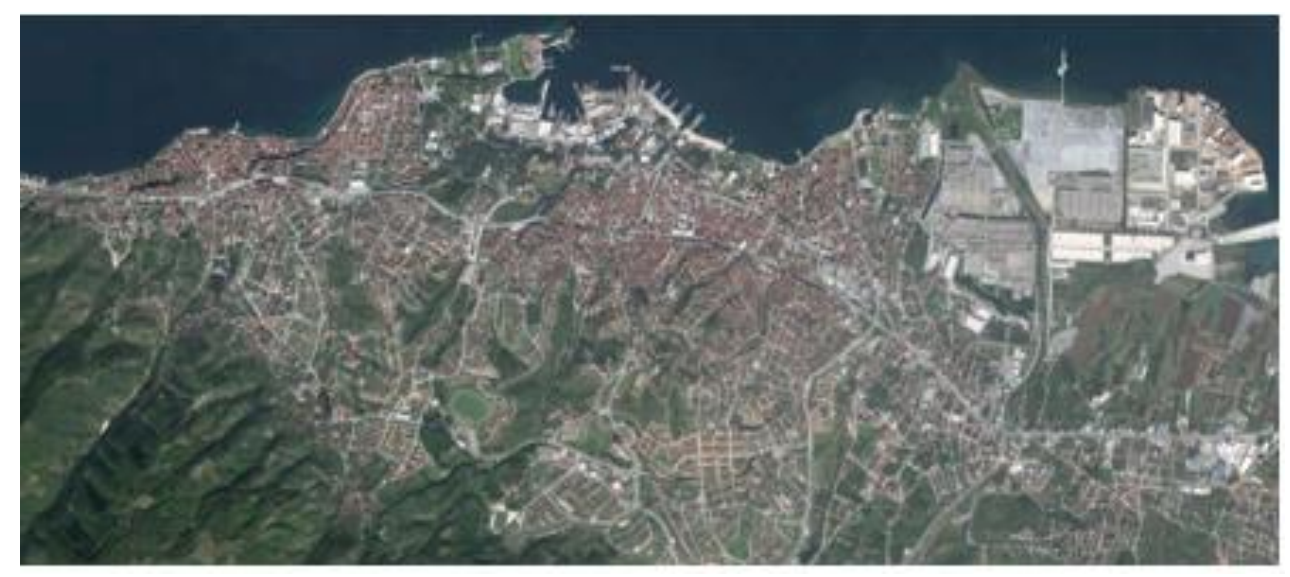

Şekil 1. Proje bölgesinin konumu

Kentin en önemli arteri olan D-130 Karayolu'nun geometrik özelliklerine bakıldığında bölünmüş ve 2 x 2 olarak çalışmakta olduğu görülmektedir. Değişken emniyet ve refüj genişliklerinin bulunduğu D-130 Karayolu'na kentin birçok noktasından bağlantı bulunmaktadır. Gerek ulaşım hiyerarşisine aykırı olarak direkt D-130 Karayolu'na bağlanan lokal yollar, gerekse arter çevresinde yer alan yerleşim yerlerinin otopark noktalarından erişim sağlanması D-130 Karayolu için kapasite sorunları oluşturmaktadır. Bunlara ek olarak, D-130 Karayolu üzerinde toplu taşıma durakları bulunmaktadır. Şehirlerarası otobüsler ile ağır taşıtlar ile birlikte toplu taşıma araçlarının da yan yol gibi bir yapılanma dışında direkt olarak D-130 Karayolu üzerindeki duraklarda indi-bindi yaptırması D-130 Karayolu kapasitesini etkileyen diğer faktörlerdir.

\section{TQD}


D-130 Karayolu kent geçişi üzerinde 4 sinyalize kavşak noktası bulunmaktadır. Bunlar;

- İnönü Caddesi - D-130 Karayolu Kesişimi Kavşağ1

- 22. Sokak - D-130 Karayolu Kesişimi Kavşağ 1

- Amiral Sağlam Caddesi - D-130 Karayolu Kesişimi Kavşağı

- Donanma Caddesi D-130 Karayolu Kesişimi Kavşağ1

\section{1. İnönü Caddesi- D-130 Karayolu Kesişimi Kavşağı}

İnönü Caddesi ile D-130 Karayolu kesişimi kavşağı mevcut durumda 3 kollu, hemzemin ve sinyalize bir T kavşaktır. Kavşağın kuzey kolu olan İnönü Caddesi çift yöndür ve 2 x 1 şeklinde çalışan bir caddedir. Kavşakta caddeyi karşılayan bir güney kolu olmadığından dolayı İzmit yönünden sola dönüş yapılamamaktadır. (Bkz: Şekil 2)

Kavşak ağzına yakın konumlarda toplu taşıma durakları olduğu tespit edilmiştir. Ayrıca, koridor çevresindeki yerleşimlerin önündeki kaldırımlar yerleşimlerin otoparklarına erişim için de kullanılmaktadır.

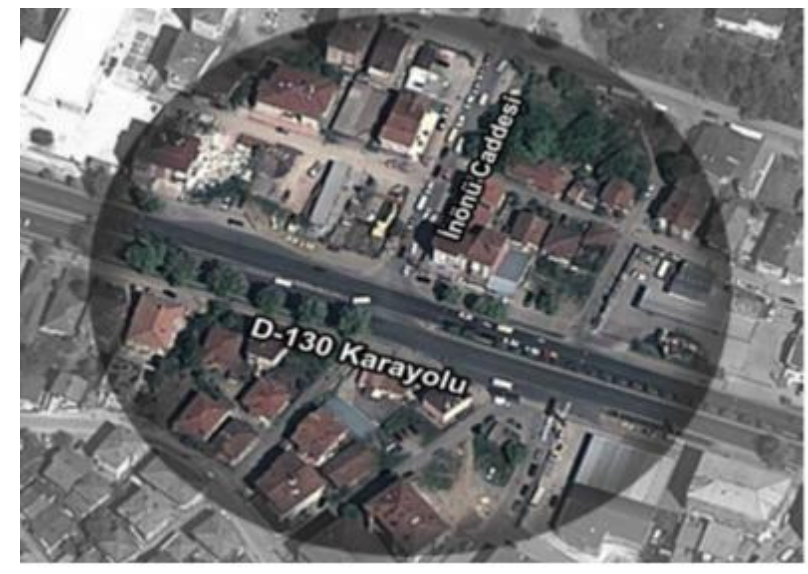

Şekil 2. İnönü Caddesi Kavşă̆

\subsection{Sokak- D-130 Karayolu Kesişimi Kavşağı}

22. Sokak ile D-130 Karayolu kesişimi kavşağı da 3 kollu ve sinyalize bir kavşaktır. Sinyalizasyon sistemi D-130 Karayolu'nda yer almaktadır. 22. Sokak'tan sola dönüş yasak, sağa dönüş ise kontrolsüzdür. Hemzemin geçişin olduğu kavşağın güneyinde D-130 Karayolu'na bağlantıları bulunan düşük nitelikli yollar bulunmaktadır. Ancak bu yollara doğu istikametinden gelen araçların herhangi bir erişim olanağı yoktur. (Bkz: Şekil 3) Ayrıca 22. Sokak girişinin bulunduğu cephede yer alan konut kullanımları için ayrılmış otopark bölgesinden direkt kavşağa bağlantı sağlanmaktadır. Bu durum kavşak ortasında tanımsız geometrilerin ortaya çıkmasına sebep olmaktadır. D-130 Karayolu üzerinden 22. Sokağa sola dönüşler için herhangi dönüş cebi ayrılmamış olması da bu durumla paraleldir. 


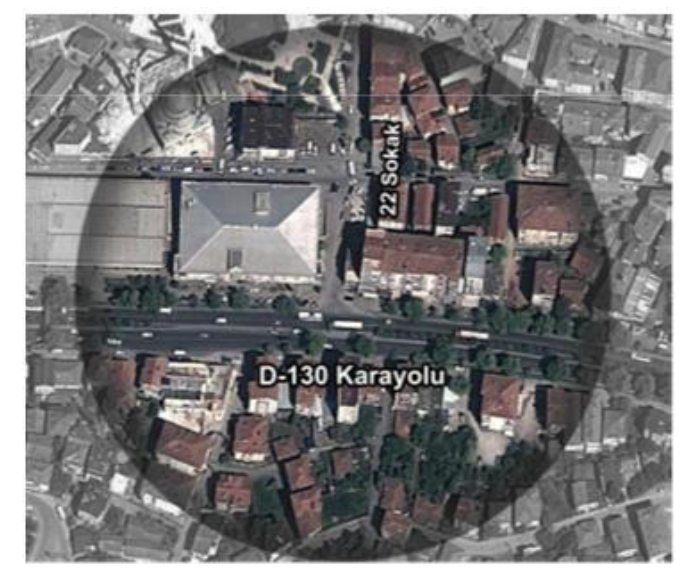

Şekil 3. 22. Sokak Kavşă̆ı

\subsection{Amiral Sağlam Caddesi- D-130 Karayolu Kesişimi Kavşağı}

Amiral Sağlam Caddesi D-130 Karayolu üzerinden kent merkezine erişecek araçların yoğun olarak kullandıkları alternatiflerden biridir ve bu aksın D-130 Karayolu ile kesişimi ile ortaya çıkan kavşak kentin erişim şeması için oldukça önemli bir konumdadır. D-130 Karayolu üzerindeki diğer sinyalize kavşaklar gibi Amiral Sağlam Caddesi kesişimi de 3 kollu ve sinyalize bir kavşaktır. Kavşakta Amiral Sağlam Caddesi üzerinden sağa dönüşler ile D-130 Karayolu üzerinden Amiral Sağlam Caddesi'ne sağa dönüşler yönlendirme adaları ile ayrılmıştır. Ancak D-130 Karayolu üzerinden güneyde yer alan yerleşim yerlerine erişim imkânı sağlanmamıştır. Kavşağın D-130 Karayolu, doğu kolu üzerinde yaya geçidi bulunmaktadır. (Bkz: Şekil 4)

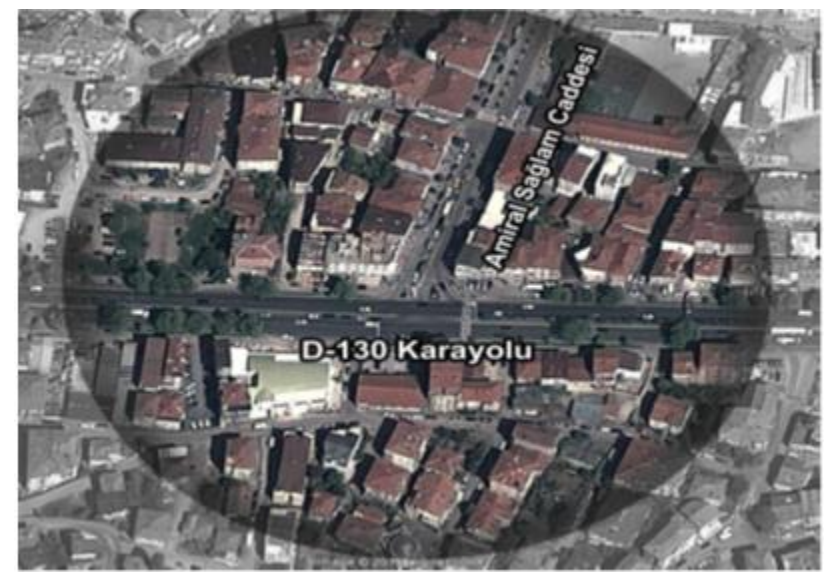

Şekil 4. Amiral Săglam Caddesi Kavşă̆

\subsection{Donanma Caddesi- D130 Karayolu Kesişimi Kavşağı}

Donanma Caddesi - D-130 Karayolu Kesişimi Kavşağı D-130 Karayolu kent geçişinin batı ucunu oluşturan, sinyalize ve hemzemin bir kavşaktır. Kavşağı güney kolunu güney istikametinde tek yön olan 165 sokak ile D-130 Karayolu bağlantısı çift yön olan İstiklal Caddesi oluşturmaktadır. Kavşakta D-130 Karayolu üzerinden Donanma Caddesi'ne sağa dönüşler ve Donanma Caddesi'nden sağa dönüşler yönlendirme adası ile diğer kavşak operasyonlarından ayrılmıştır. D-130 Karayolu doğu kolunda yaya geçidi yer almaktadır. Ayrıca kavşak geometrisi genel olarak değerlendirildiğinde dönüş hareketleri gerçekleşirken tanımsız alanların kaldığı tespit edilmiştir. Özellikle kentin önemli sorunlarından biri olan kuzey - güney geçişleri bu kavşak geometrisi kaynaklı olarak daha da zorlaşmaktadır. Kuzey

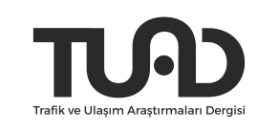


güney doğrultulu kavşak operasyonlarına ek olarak D-130 Karayolu üzerinden güneydeki yerleşim yerlerine sola dönüş imkânı da bulunmamaktadır. (Bkz: Şekil 5)

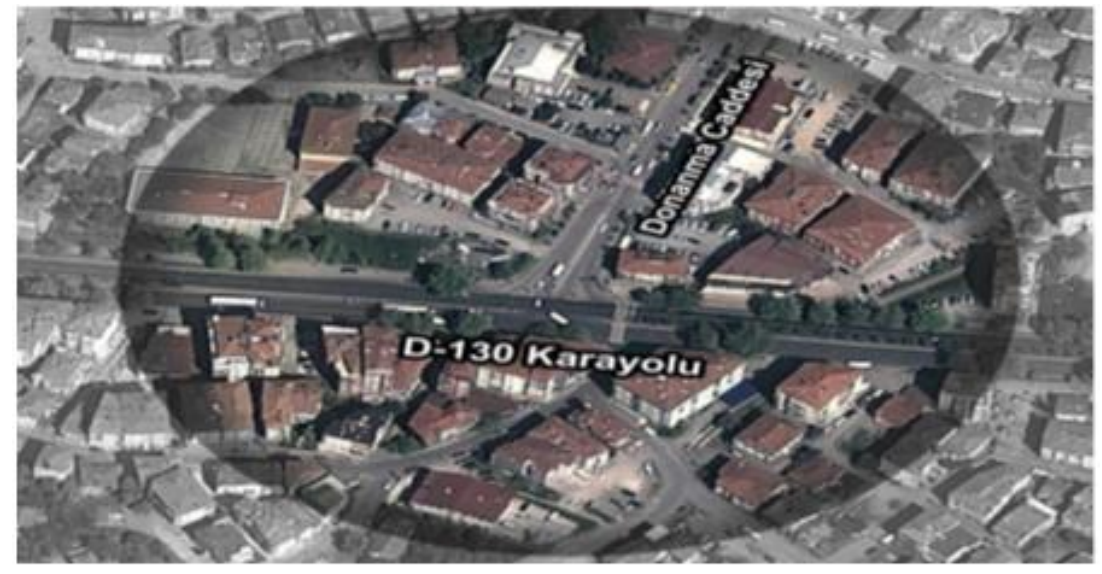

Şekil 5. Donanma Caddesi Kavşă̆

\section{Sorunlar}

Kentsel mekânlar tasarlanırken kent içerisindeki kullanımlara uygun olarak dolaşım mekânları yani yol ağları da oluşturulmaktadır. Yol ağları kurulurken bu yollar arasında da bir kademelenme oluşturulmakta ve buna göre yolların tipleri, yönleri ve kapasiteleri belirlenmektedir.

Literatürde birçok farklı dolaşım şeması bulunmakta ve kentlerin yapılarına göre bu dolaşım sistemlerinin biri veya birkaç farklı türü bir arada kullanılmaktadır. Örneğin kent merkezi alanlarında çoğunlukla tercih edilen tek yönlü işleyen dolaşım şemaları toplam yolculuk mesafeleri ve kesitte ortalama yolculuk hacimlerini arttırmasına rağmen ağ üzerindeki kesişme sayısı azaldığı için ortalama yolculuk sürelerinde azalmalar sağlamaktadır.

Dolaşım şemasının oluşturulmasında yayalaştırma, bisiklet yolları, toplu taşıma güzergâhları ve otopark konumları ile ilgili kararlar göz önünde bulundurularak gerekli düzenlemeler yapılmıştır.

Gölcük ilçesi içinden geçen D-130 Devlet Yolu kent üzerinde kentsel ve sosyal etkiler yarattığ1 gibi trafik sorunları da yaratmaktadır. Ancak trafik sorunları bu yoldan ibaret olmayıp kent merkezi çevresinde de bazı sorunlar bulunmaktadır. Bu sorunlar şu şekilde sıralanmıştır. D-130 Karayolu üzerinde transit trafik ile kent içi trafik birbirinden ayrılmamaktadır.

D-130 Karayolu geometrik özellikleri göz önünde bulundurulduğunda sadece kentsel değil bölgesel ölçekte önem taşıyan bir karayolu olduğu için transit trafiğe de hizmet vermektedir. Kent içi trafiğine göre daha farklı bir araç türlerini ortaya çıkmasına neden olmaktadır. $\mathrm{Bu}$ durumla beraberinde, kenti transit geçecek araçlar kent içi trafiğine katılacak araçlara, kent içi trafiğine katılacak araçların da transit trafiği olumsuz yönde etkilediği gözlemlenmiştir.

Kocaeli Ulaşım Ana Planı kapsamında gerçekleştirilen perde sayımlarından görüldüğü üzere batıdaki Karamürsel perdesi ile Gölcük Perdesi arasındaki hacim değerlerinde \%61 değerinde bir fark olduğu görülmektedir. Diğer bir deyişle D-130 üzerindeki trafiğgin yaklaşık \%40'1nı transit trafik oluşturmaktadır (Bkz: Şekil 7) (Kocaeli Ulaşım Ana Planı Sonuç Raporu, 2014). 


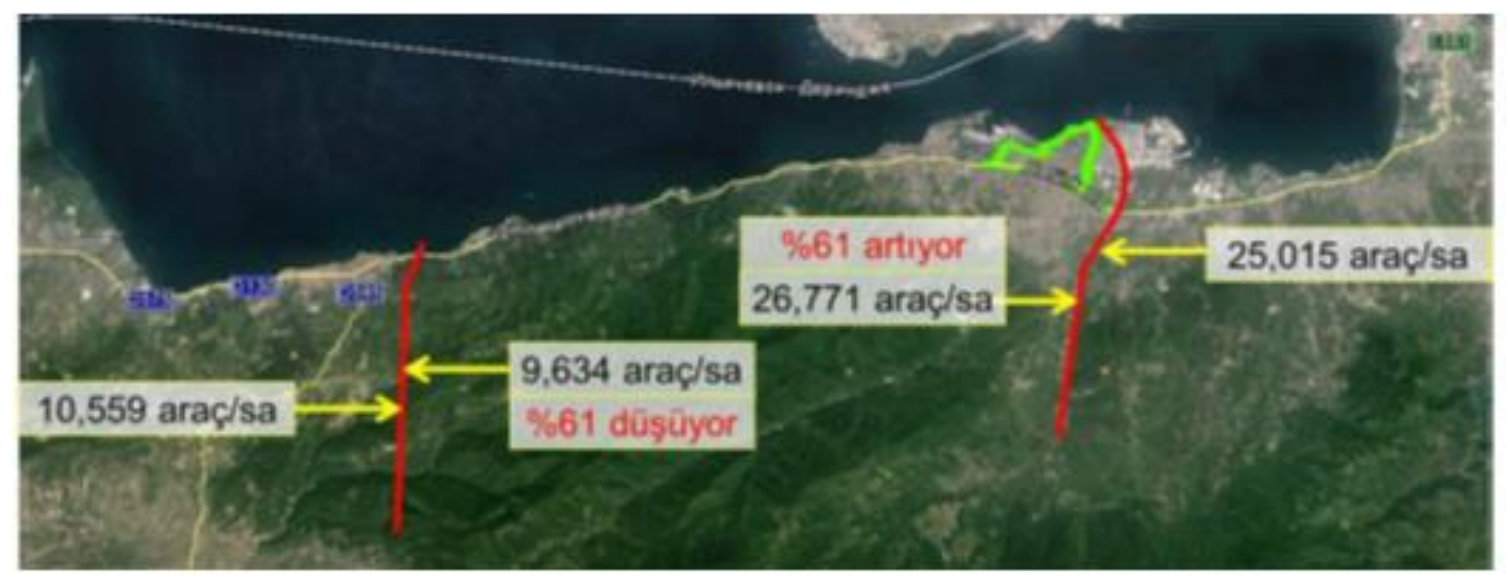

Şekil 6. Perde Sayımlarının Analizi

Kent içi trafiği ile transit trafiğin ayrılmaması ayrıca güvenlik problemlerine de neden olmaktadır. Aşağıdaki şekilden görüldüğü üzere bölgedeki 80 ölümlü-yaralanmalı kazanın 40 tanesi D-130 Karayolu üzerinde ve 21 tanesi de karayolu üzerindeki sinyalize kavşaklar üzerinde gerçekleşmiştir (Kocaeli Ulaşım Ana Planı Sonuç Raporu, 2014).

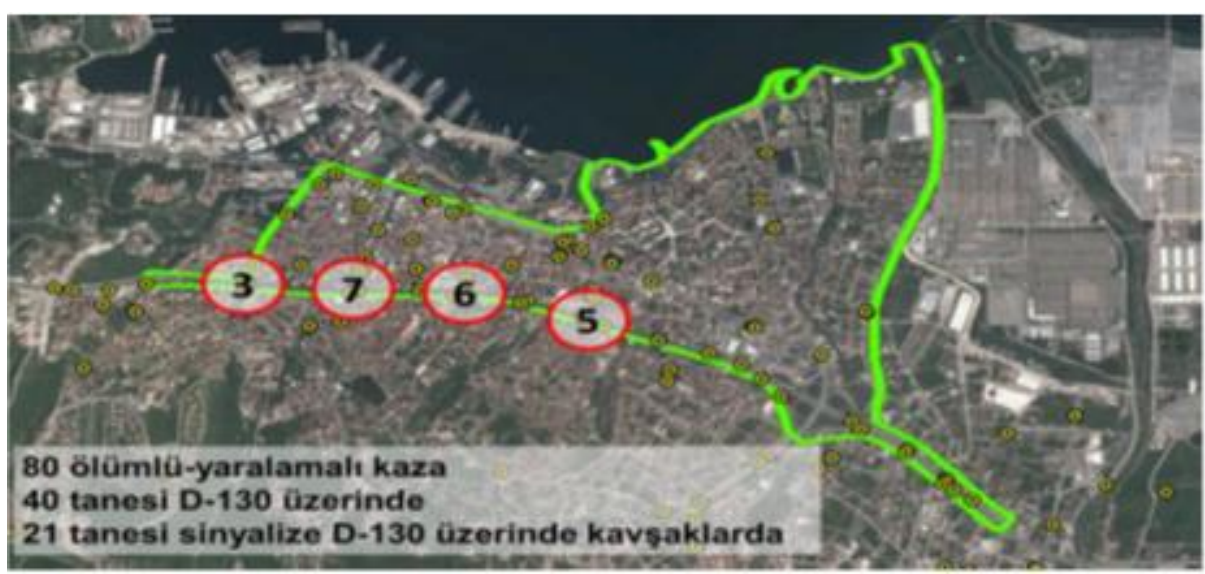

Şekil 7. Trafik kaza verileri

D-130 Karayolu transit trafik ile kent içi trafiğin birbirinden ayrılmaması, birçok noktada D130 Karayolu'na kontrolsüz katılımların olmasına neden olmaktadır. Bu durumda da trafik akışı olumsuz etkilenmektedir (Çelebi, 2014).

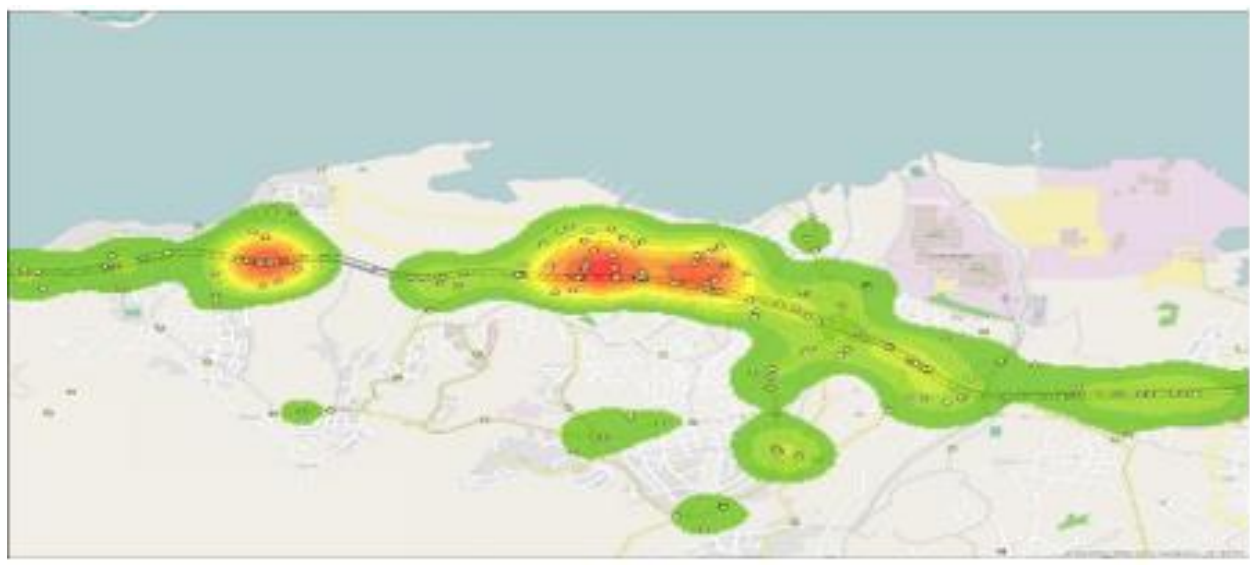

Şekil 8. Trafik kaza noktalarının yoğunlaştığı bölgeler

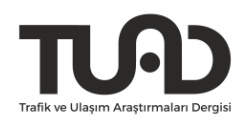


Kent merkezi içerisinde ve D-130 Karayolu geçişinde kazaların yoğunlaştığı bölgeler belirlenmiştir.

Tablo 1. Kaza sonucu analizi (KBB Yol Güvenliği Çalışması Verileri)

\begin{tabular}{lrlr}
\hline Kaza Türü & Sayı & Kaza Sonucu & Sayı \\
\hline Arkadan çarpma & 14 & Diğer & 64 \\
Devrilme, savrulma, takla & 5 & Araçtan insan düşmesi \\
Duran araca çarpma & 2 & Devrilme, savrulma, takla & 1 \\
Engel/cisim ile çarpışma & 4 & Duran araca çarpma & 5 \\
Girilmemiş & 2 & Karşıllklı çarpışma & 4 \\
Karşllıklı çarpışma & 2 & Yandan çarpma & 1 \\
Yandan çarpma & 29 & Yayaya çarpma & 2 \\
Yayaya çarpma & 21 Zincirleme çarpışma & 2 \\
Yoldan çıkma & 1 & \\
Genel Toplam & $\mathbf{8 0}$ Genel Toplam & 1 \\
\hline
\end{tabular}

Kocaeli Büyükşehir Belediyesi tarafından yürütülen Yol Güvenliği Çalışması kapsamında 2013-2016 yılları arasında Kocaeli İl Emniyet ve Jandarma birimlerince tutulan ölüm-ölümlü yaralanmalı trafik kaza tutanaklarından elde edilen veriler ile oluşturulan analizler sonucu koridor boyunca gerçekleşen kazaların oluş sebepleri (Kaza Türü) incelenmiştir.

Koridor boyunca yapılan analizler sonucu yaşanan trafik kazalarının 29 tanesi yandan çarpma, 14 tanesi arkadan çarpma, 21 tanesi ise yayaya çarpma şeklinde gerçekleştiği görülmektedir. (Bkz: Tablo 1)

D-130 Karayolundan İzmit yönünden kentin güneyindeki konut alanlarına dönüş yoktur. İzmit istikametinden gelen araçlar D-130 Karayolu güneyinde yer alan konut bölgelerine direkt olarak sola dönüş yapamamakta ve kent merkezi trafiğine katılmaktadır. Bu durum hem kent merkezi trafik yükünü artırmakta hem de konut bölgelerine erişmek isteyen sürücülere zaman kaybettirmektedir. (Bkz: Şekil 9)

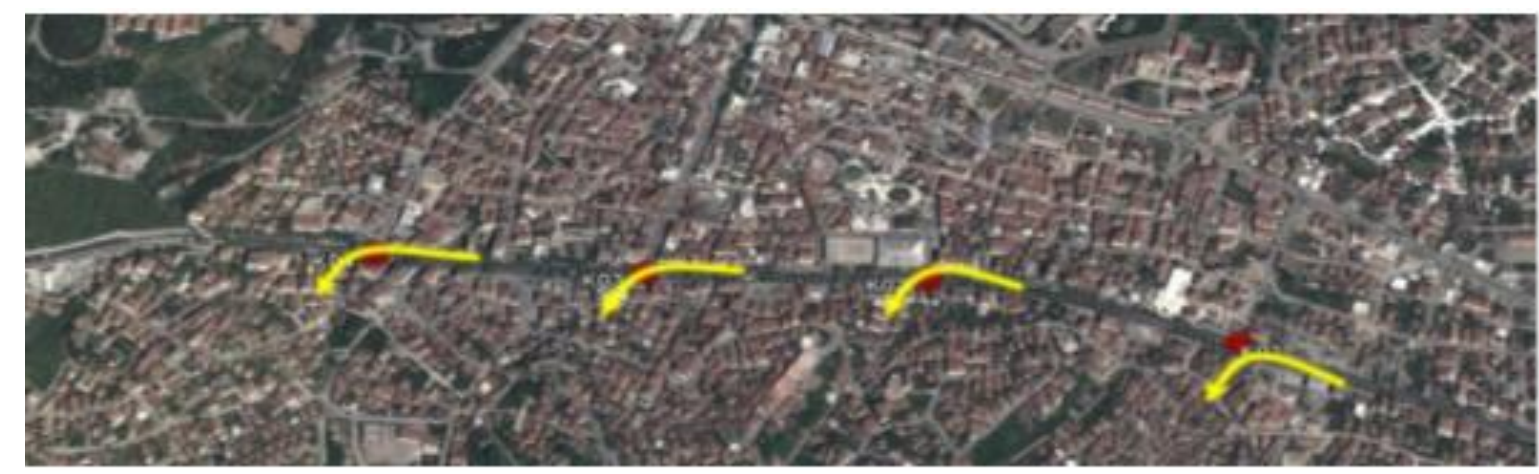

Şekil 9. Sola dönüş̧ imkânlart

D-130 Karayolu üzerinde bulunan 4 kavşakta sinyal koordinasyonu bulunmamaktadır.

Şekilde görüldüğü üzere D-130 Karayolu üzerinde 4 tane sinyalize kavşak bulunmaktadır. Kentin en önemli arteri olan bu yoldaki kavşaklar üzerinde entegre çalışan bir sinyalizasyon sistemi olmadığından dolayı kavşak noktalarındaki gecikme değerleri artmakta ve kuyruk boyları uzamaktadır. 


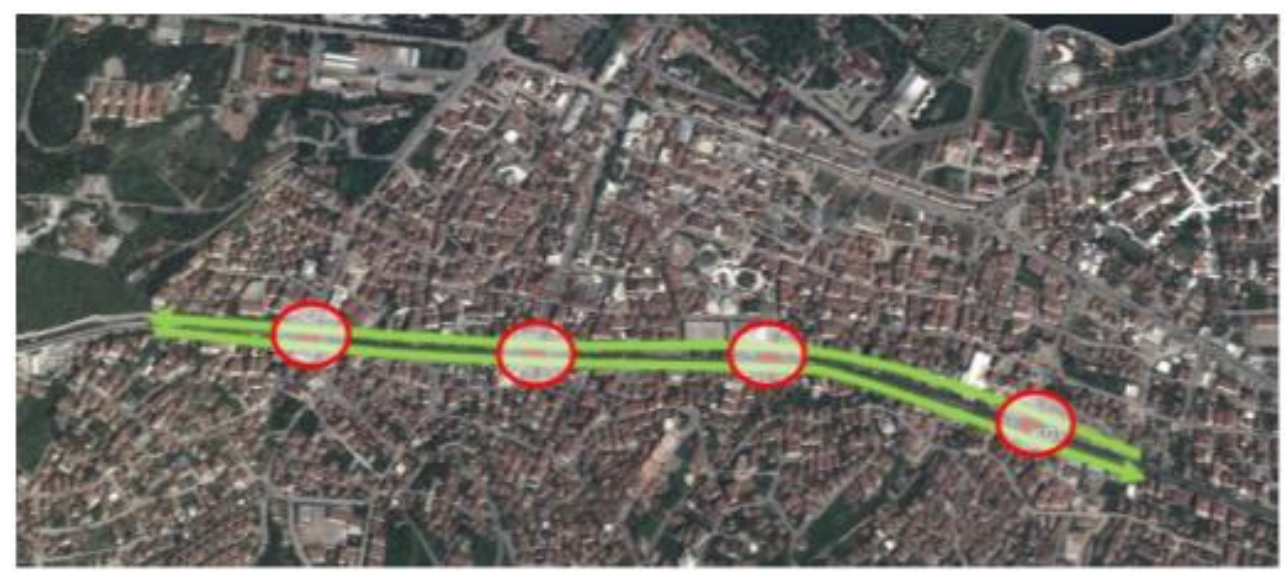

Şekil 10. D-130 Karayolu üzerindeki sinyalize kavşaklar

D-130 Karayolu üzerindeki kavşaklarda geometrik sorunlar bulunmaktadır. Yukarıda görülen kavşak noktaları detaylı incelendiğinde kavşaklarda trafik operasyonlarını etkileyen geometrik sorunlar olduğu tespit edilmiştir. Ayrıca bu sorunlarından kaynaklı ve bunlara ek olarak, kavşaklarda sürücüler kural ihlalleri de yapmaktadır. 22 Sk. - D-130 Karayolu kesişimi kavşağına bakıldığında, Donanma Caddesi istikametinden D-130 Karayolu üzerinde sola dönüşler yasaklanmıştır. Yapılan gözlemlerde ve trafik sayımlarında tespit edildiği üzere sola dönüş için belli bir talebin olduğu kavşak noktasında geometrik olarak bu operasyonun gerçekleşmesi mevcut durumda trafik güvenliğini tehlikeye sokmaktadır.

D-130 Devlet Yolu'nun işlevi, tasarım ve işletilmesi kentsel trafik sorunu yaratmaktadır. Sanayi üretiminin yoğun olduğu Gebze, Sakarya ve Gölcük ilçesi içindeki yoğun sanayi alanları ile Yalova- Bursa kentleri ve Ege Bölgesi'ni bağlayan yegâne yol D-130 Devlet Yolu Gölcük içinden geçmektedir. Ağırlıklı kamyon ve tır trafiğginden oluşan araç yükü Gölcük üzerinde ağır bir trafik baskısı yaratmaktadır. D-130 Devlet Yolu aynı zamanda kentsel trafik tarafindan da aktif olarak kullanılmaktadır. Şehirlerarası transit trafik ile kent içi trafiği iç içe yaşanması trafik yükünü iyice arttırmakta ve yayaların ağır trafik altında yaşamasına, kavşakların da gerçek kapasitelerinde çalışamamasına neden olmaktadır.

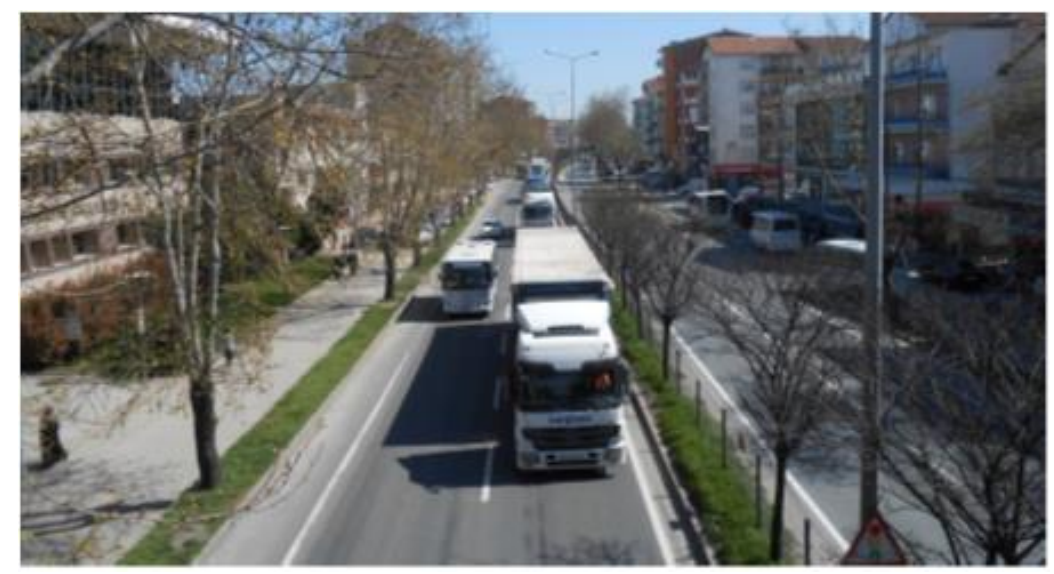

Şekil 11. D-130 Karayolu kesiti

\section{4. Çözüm Önerilerinin Karşılaştırılması}

Gölcük kentinde kent merkezi ile yerleşim dokusu arasında doğu batı ekseninde uzanan D-130 Karayolu üzerinde yerinde yapılan gözlemler ile tespit edilen mevcut sorunların çözümüne ilişkin olarak iki farklı konseptte alternatifler geliştirilmiş ve D-130 Karayolu üzerindeki sorunlara çözümler üretilmiştir.

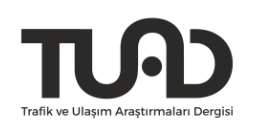


Kentin tespit edilen en önemli sorununun D-130 Karayolu'na yolun kuzey ve güney kesimlerinden birçok noktada bağlantının gerçekleştirilmesi ve trafik akışının sürekliliğinin olumsuz etkilenmesi olduğu tespit edilmiştir. Ayrıca İzmit istikametinden D-130 Karayolu'nun güneyinde bulanan yerleşimlere sola dönerek direkt erişim imkânının bulunmaması birçok aracin kent merkezine girmesine sebep olmaktadır.

\subsection{Alternatif 1}

Üretilen ilk alternatif D-130 Karayolu üzerindeki transit trafiğinin sürekliliğin ön planda tutan ve gerek yolun kuzeyinde yer alan kent merkezine gerekse yolun güneyindeki yerleşim yerlerine yan yollar üzerinden erişim sağlayan bir yapı önermektedir. Transit trafiğgin D-130 Karayolu üzerinden direkt geçişinin sağlanmasına ek olarak D-130 Karayolu üzerinden kent merkezi bölgesine ya da güneyde yer alan yerleşimlere erişmek isteyenlerin öncelikli olarak D130 Karayolu yan yoluna, oradan da kent içi yollara erişimi sağlanmaktadır. Böylelikle D-130 Karayolu - D-130 Karayolu Yan yolu - Toplayıcı Yol- Lokal Yol hiyerarşisi benimsenmiştir.

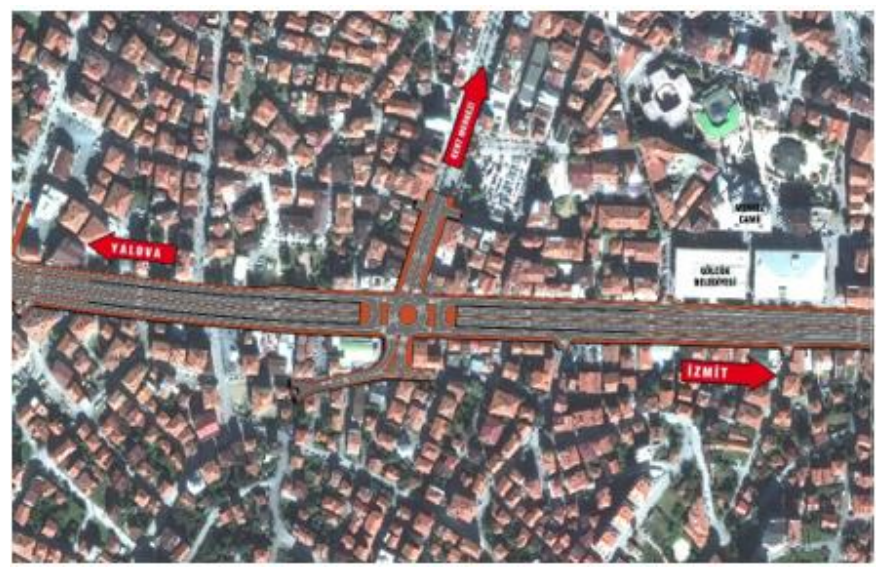

Şekil 12. Farklı Seviyeli Kavşak (Dal-Çık) Projesi

Şekil 12'de görüldüğü üzere Gölcük Kent Merkezi trafiğini oluşturan kent içi ve transit trafiği birbirinden ayırarak, trafik güvenliğini arttırmış ve düzenlenmiş olmaktadır. Aynı zamanda transit trafik yerin altına alınarak kentin kuzey-güney ilişkisi hemzemin kavşak üzerinden yapılması amaçlanmıştır.

\subsection{Alternatif 2}

Alternatif iki de ise Gölcük kent merkezi içerisinde yer alan sırasıyla; İskele Yolu Caddesi, Belediye Kavşağı, Amiral Sağlam Caddesi, Donanma Kavşağı mevcuttaki sinyal süreleri ve faz planları üzerinde değişiklikler yapılarak getirilen öneride trafikte yaşanan kuyruklanmalar ve gecikmelerin önüne geçilmeye çalışılmıştır. 


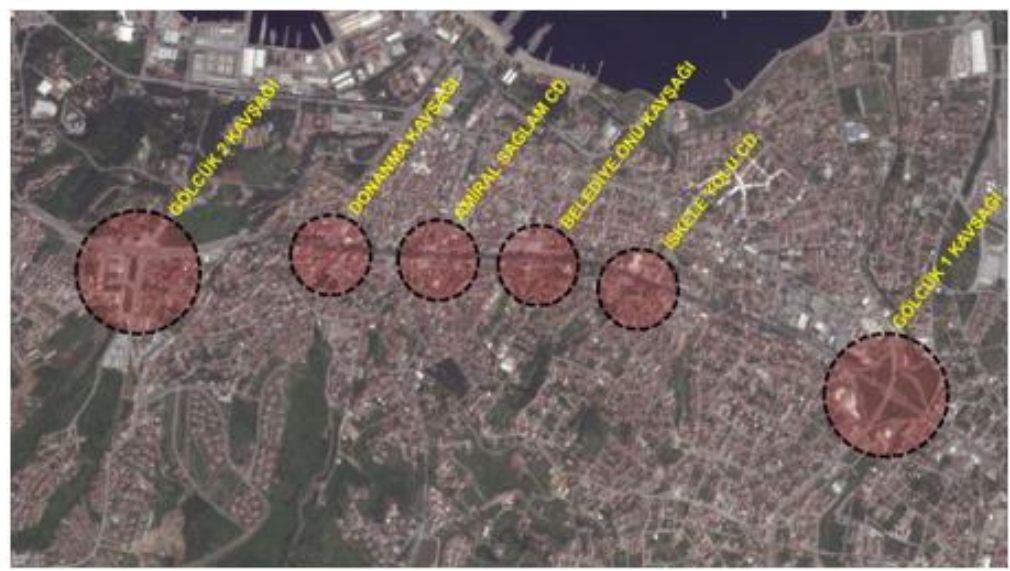

Şekil 13. Gölcük Kent Merkezi Kavşakları

Koridor üzerindeki tüm kavşaklar 2 fazlı olarak planmış ve Gölcük Kent Merkezinden İzmit yönüne çıkışlar da belirli notlar üzerinden sağlanarak çözüm üretilmiştir.

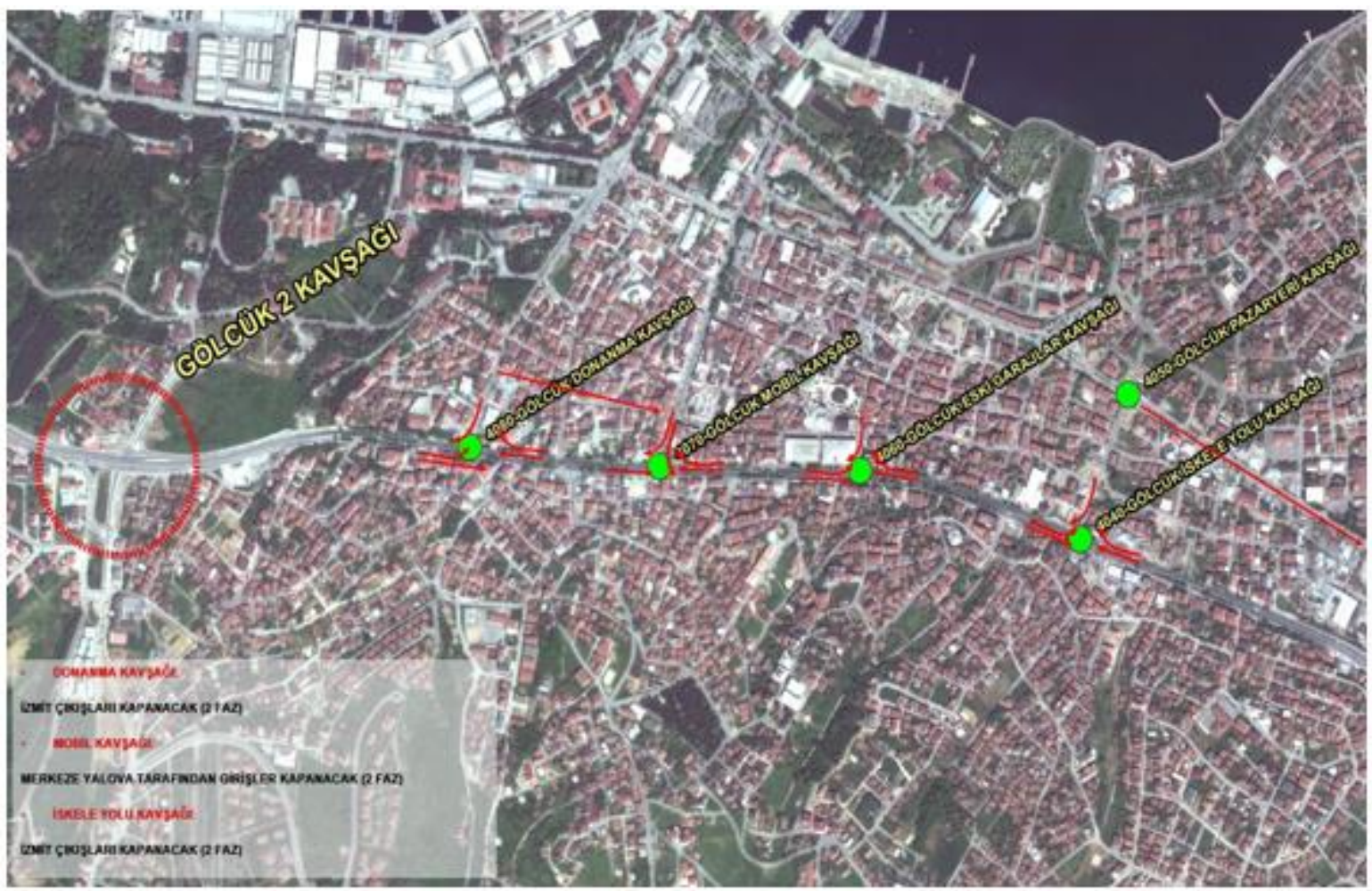

Şekil 14. Faz Planları ve Kavşak Yönleri

Şekil 14'te görüldüğü üzere; Donanma kavşağında İzmit yönüne çıkışlar kapatılarak 2 fazlı sinyalli kavşak olması önerilmiştir. Mobil kavşağında benzer bir karar ile Yalova tarafından Gölcük Kent merkezine girişler kapatılmış ve 2 fazlı sinyalize kavşak haline getirilirken, İskele Yolu kavşağının ise İzmit yönüne çıkışları kapatılarak 2 fazlı sinyalize kavşak olarak önerilmiştir. 


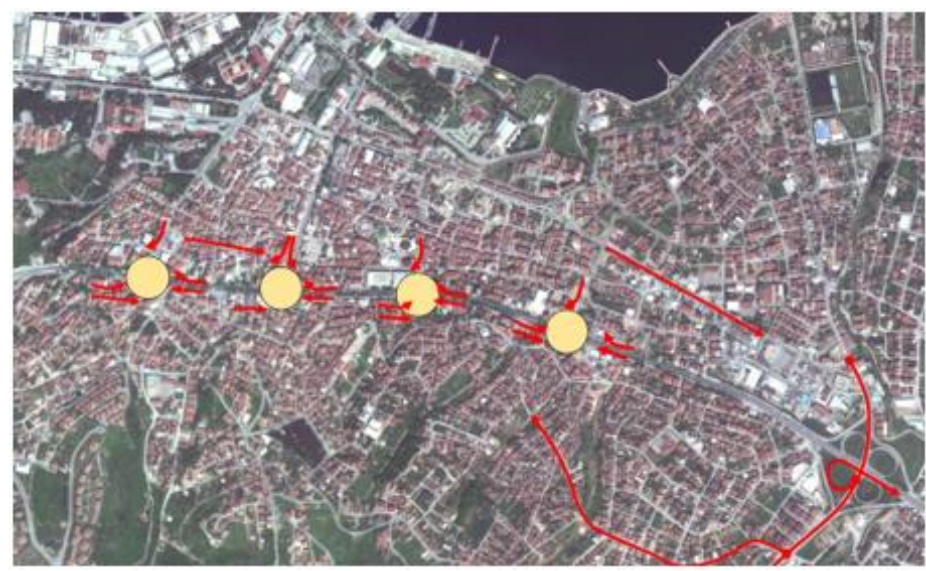

Şekil 15. Gölcük Kent Merkezi Kavşakları Yön Önerileri

\section{Sonuç ve Öneriler}

\subsection{Bulgular}

Genel olarak getirilen önerileri değerlendirecek olursak 1. alternatifte Amiral Sağlam Caddesi farklı seviyeli kavşak (dal-çık) ile geçilmiş olup kuzey-güney geçişleri oluşan kavşak üzerinden sağlanarak transit trafik ile kent içi trafiğinin birbirinden ayrılması sağlanmıştır. Bu çözüm ile trafik güvenliği ve gecikmelerin önüne geçmeyi hedeflerken; alternatif-2 seçeneğinde ise dalçık çözümü yerine mevcut kavşaklarda dönüşlerin düzenlenerek faz sayısını düşürmek amaçlanmış ve trafikte yaşanan karmaşanın önüne geçilmesi hedeflenmiştir.

PTV Vissim yazılımında koridor halihazırda olduğu şekliyle linkler çizilerek modeli kurulmuş ve mevcuttaki trafik hacimleri sisteme girilmiştir. (Bkz: Şekil 16)

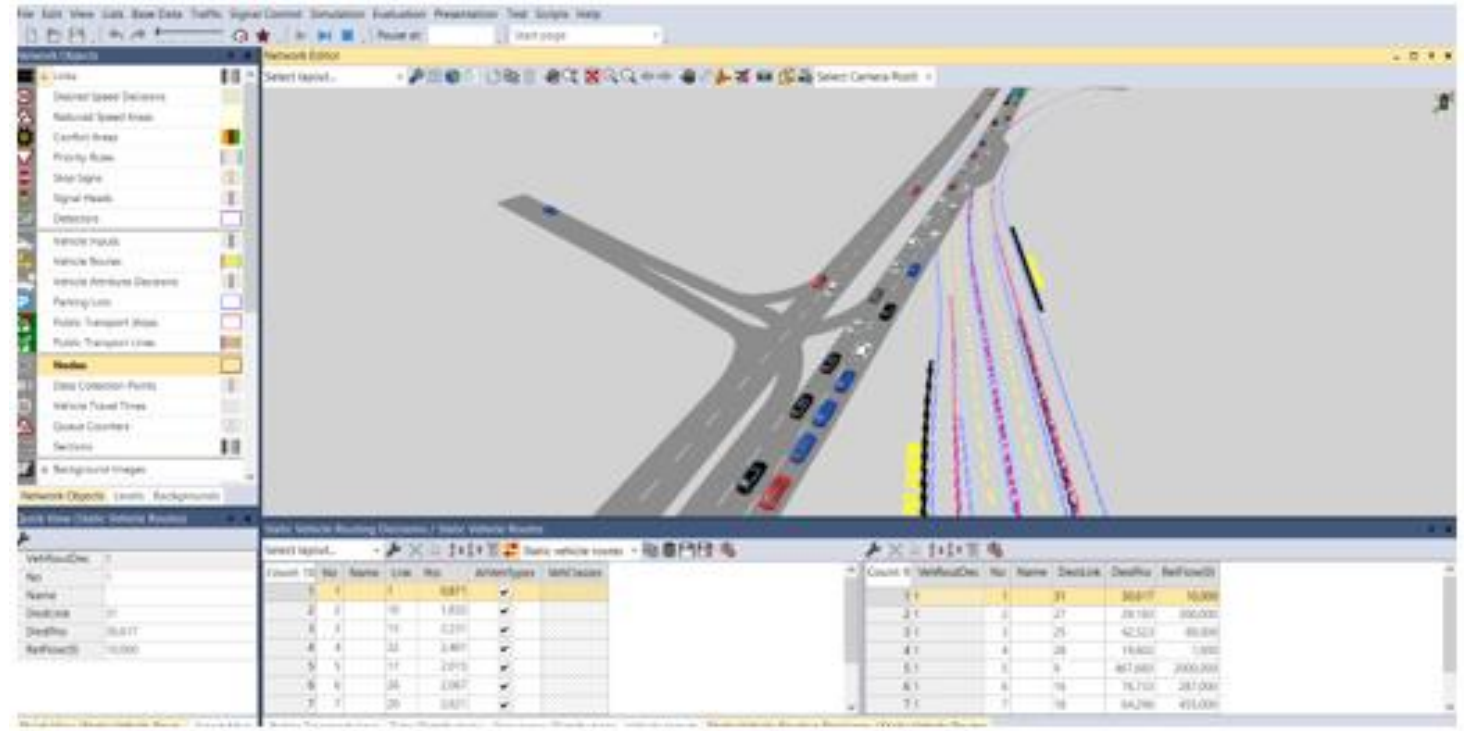

Şekil 16. PTV Vissim Trafik Hacimlerinin Girilmesi 


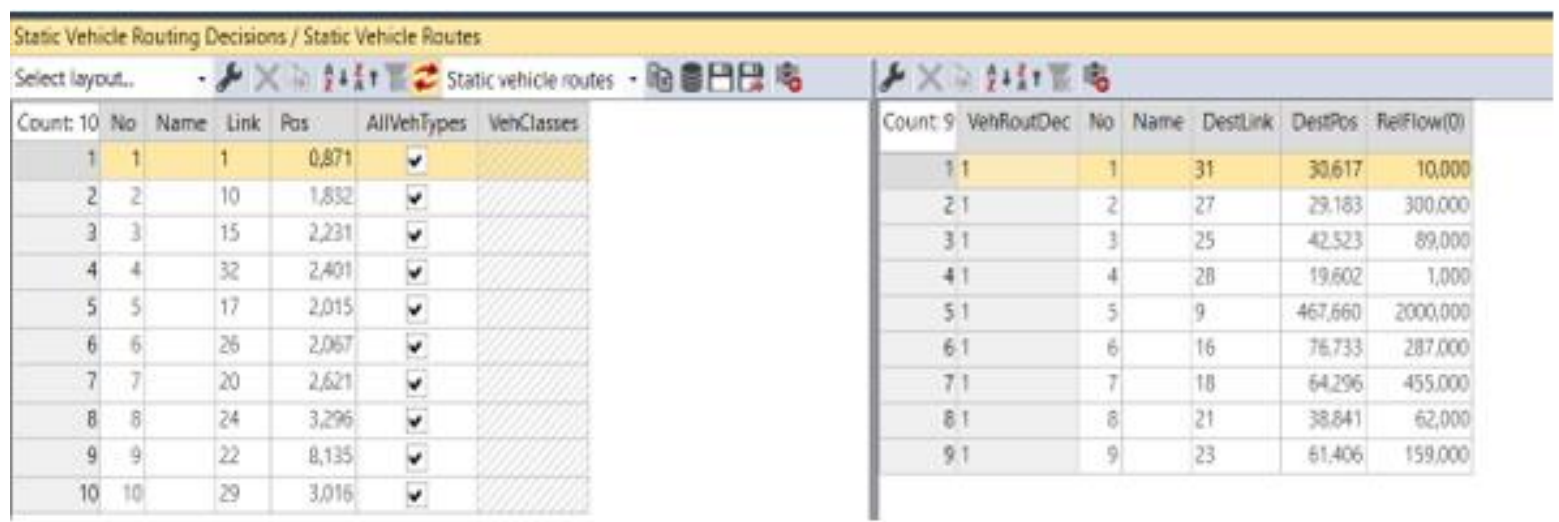

Şekil 17. PTV Vissim Trafik Hacimlerinin Modele Girilmesi

Koridor üzerindeki kavşakların sinyal faz planları da aynı şekilde simülasyon girilmiştir. Bu şekilde gerçeğe en yakın modeli yansıtan mikro simülasyon modeli çalıştırılarak mevcut durum analizleri ortaya koyulmuştur. (Bkz: Şekil 18)

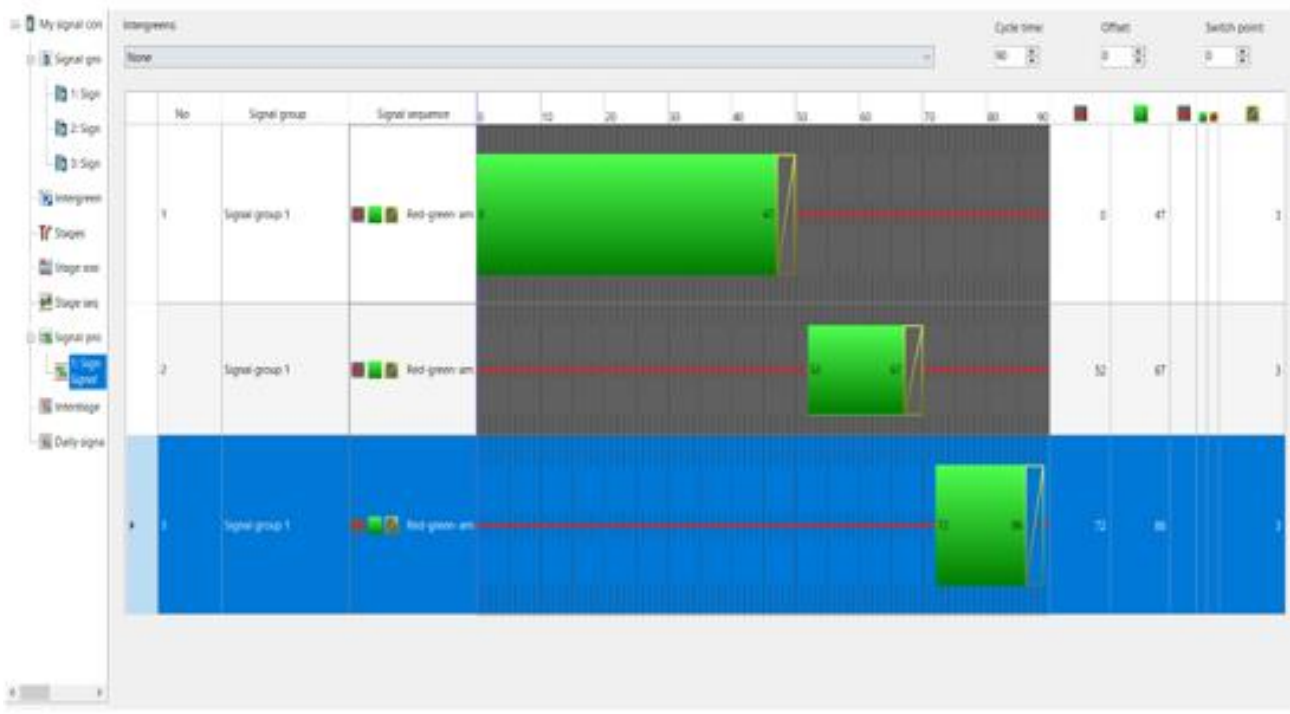

Şekil 18. PTV Vissim Sinyal Faz Planlarının Sisteme Girilmesi

Yapılan analizlerin incelenmesi sonucu oluşturulan alternatifler, sinyal faz planlarıyla beraber mevcut simülasyon modelindeki aşamaların tekrarlanmasıyla alternatif simülasyon modelleri oluşturulmuştur.

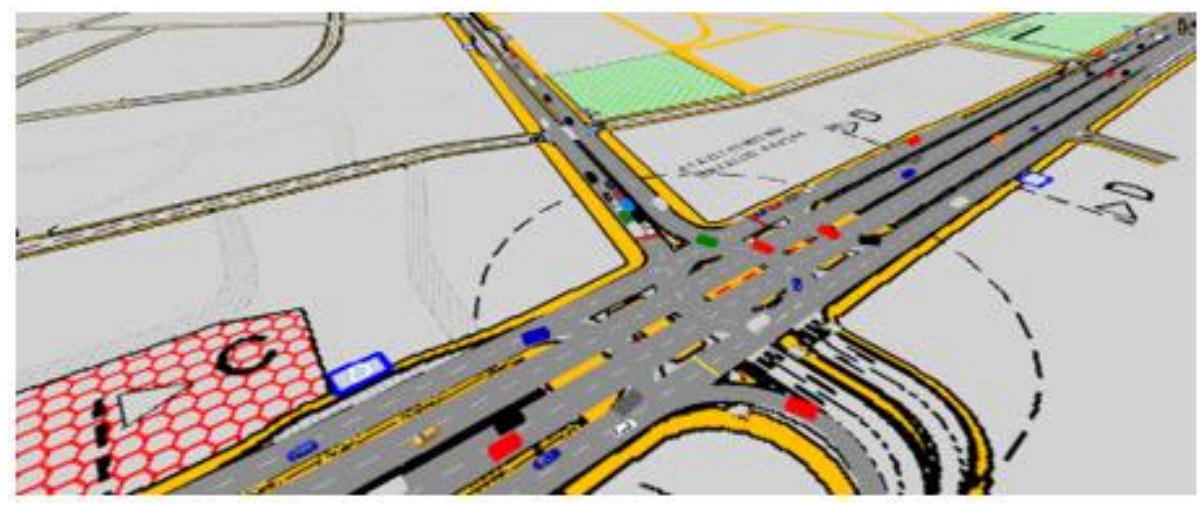

Şekil 19. PTV Vissim 3D Görünüm 
Yapılan analizlerde dal-çık çözümünde yaya geçişleri dal-çık üzerinde olması, yol platform genişliğinin büyük ve farklı seviyeli bir kavşak türü olması nedeniyle yaya geçişleri için üstgeçit ihtiyacını doğururken, faz planlarında yapılacak olan çözümde her kavşak noktasında sinyalle geçişler mümkün olacaktır.

Öneri iki alternatif de PTV Vissim yazılımı yardımıyla analiz edilmiş ve sonuçları değerlendirilmiş olup sonuçlar Tablo 2'deki gibidir. Alternatifler incelendiğinde dal-çık önerisinde ortalama gecikme süresi $58 \mathrm{sn}$, ortalama hızın $41 \mathrm{~km} / \mathrm{h}$, toplam gecikme 107 , ortalama durma 2,2 olduğu görülmektedir. Faz düzenleme önerisinde ise; ortalama gecikme 51 sn, ortalama hiz $45 \mathrm{~km} / \mathrm{h}$, ortalama durma gecikmesi $21 \mathrm{sn}$, toplam gecikmesinin ise $21 \mathrm{sn}$. olduğu tespit edilmiştir.

\section{Tablo 2. Alternatiflerin Değerlendirilmesi}

\begin{tabular}{lrrrl}
\hline Ă̆ Analizi & Mevcut & Dal-Çık Düzenlemesi & Faz Düzenlemesi & Birim \\
\hline Ortalama Gecikme & 110.19 & 57.06 & 51.60 & $\mathrm{Sn}$. \\
Ortalama Durma & 2.22 & 1.10 & 1.32 & Araç başına \\
Ortalama Hız & 31.15 & 41.30 & 45.21 & $\mathrm{Km} / \mathrm{s}$ \\
Ortalama Durma Gecikmesi & 46.40 & 40.68 & 21.38 & $\mathrm{Sn}$. \\
Toplam Seyahat Mesafesi & 9975.74 & 10516.71 & 10743.41 & $\mathrm{Km}$ \\
Toplam Seyahat Süresi & 320.21 & 295.80 & 237.63 & Saat \\
Toplam Gecikme & 176.58 & 107.80 & 80.50 & Saat \\
Toplam Durma Gecikmesi & 74.36 & 37.46 & 33.35 & Saat \\
Aktif Araç & 345 & 334 & 214 & Araç \\
Erişmiş Araç & 5424 & 5435 & 5402 & Araç \\
Hesaplanmamış Gecikme & 35.36 & 0.08 & 0.08 & Saat \\
Hesaplanmamış Araç & 83 & 1 & 1 & Araç \\
\hline
\end{tabular}

\subsection{Tartışma}

Yukarıdaki tablo incelendiğinde mevcut durum, dal-çık düzenlemesi ve faz düzenlenmesi önerilerinin karşılaştırmaları yer almaktadır. Mevcut duruma göre (110sn) ortalama gecikmeleri baz alacak olursak dal-çık düzenlemesinde $57 \mathrm{sn}$, faz düzenlemesinin 51 sn ye gerilediği, ortalama hızın ise dal-çık önerisinde $10 \mathrm{~km}$, faz düzenlemesinde ise $15 \mathrm{~km}$ arttığ görülmüştür.

İki alternatif de mevcut durum trafik sirkülasyonuna katkı sağladığı ve mevcut durum analizlerinden elde edilen sonuçlara göre de koridor boyunca düzenleme yapılması gerekliliğini net bir şekilde ortaya koymaktadır.

Trafik sorunlarının çözümlerinde en yapılabilir ve karlı çözüm alternatifinin seçilmesi birçok kıstası içerisinde barındırmakta olup çözüm yatırımlarının kıyaslanması sürecinin iyi değerlendirilmesi gerekliliğini göstermektedir. Değerlendirme sürecinde çözüm üretilen bölgenin gerçek ihtiyaçları, projeksiyon trafik hacimleri, yapım maliyetleri ve yatırım öncelikleri değerlendirilerek gerekirse kısa-orta-uzun vade çözüm alternatifleri olarak kıyaslanması önerilmektedir. $\mathrm{Bu}$ şekilde yapılması en doğru yatırımın, doğru zamanda yapımına başlamasına hem de bölgede yaşanan sorunların çözümüne katkı sağlaması açısından oldukça önemlidir.

Bu sebeple alışılagelmiş çözümler ve yüksek maliyetli çözümler yerine maliyet ve bütçe harcama önceliği dikkate alınarak alternatifler oluşturulmalı, çözümler irdelenirken kamulaştırma maliyetleri, sürücü alışkanlıkları, trafik güvenliği ve gecikmeler gibi maliyetler de göz önünde bulundurularak alternatif çözümler üretilmeli ve kıyaslanmalıdır. Örnekte de görüleceği üzere ilk bakışta transit trafiğin kent içi trafik ile birbirinden ayıran faklı seviyeli kavşak (dal-çık) çözümü varken, faz düzenlemesi ile yapılan çözümün daha etkili olduğu

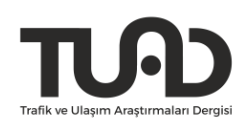


gözlemlenmiştir. Her bölgenin ayrı karakteristiği olduğu ihtiyaçlarının farklı olduğu göz ardı edilmemelidir.

Aşağıda yer alan simülasyon modellerinde de örnek kavşak noktalarından görseller alınmış olup alternatiflerin karşıllaştırmasında kullanılmıştır. (Bkz: Şekil 20)

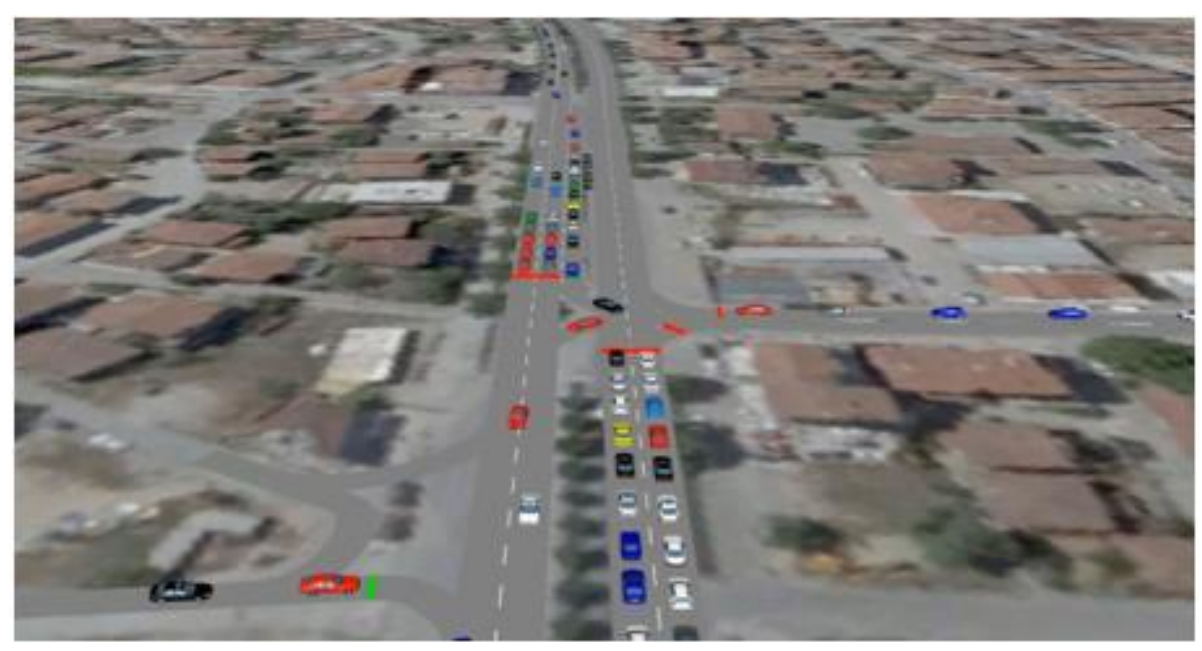

Şekil 20. PTV Vissim Modeli-İönü Kavşă̆g

Genel bir değerlendirme yapacak olursak kentlerde yapılan trafik çözümlerinin iyi irdelenmesi, yerinde trafik sayımları, kamera çekimleri vb. teknolojik uygulamalar ile verilerin analizinin uzman kişiler tarafından akıllı programlar ile yapılmasının gerekliliğini ortaya çıkarmaktadır. Aynı zamanda doğru yatırımın yapılmasına karar vermemize yardımcı olması hasebi ile de maliyet karşılaştırması yapabilmek en az maliyet ile en fazla faydayı sağlama teorisini gerçekleştirmeyi sağlayacaktır. 


\section{Kaynakça}

Çelebi, A. (2014). Konumsal kaza verilerinin coğrafi bilgi sistemleri kullanılarak analizi (Kocaeli örneği) (Yayınlanmamış Yüksek Lisans Tezi). Bahçeşehir Üniversitesi, İstanbul.

Kocaeli Büyükşehir Belediyesi Yol Güvenliği Proje Verileri (2013)

Kocaeli Ulaşım Ana Planı Sonuç Raporu (2014)

Türkiye İstatistik Kurumu [TÜİK] (2018). "İçe Nüfus İstatistikleri” 